\title{
The Genus Tetradenia (Lamiaceae): A Review of Its Ethnomedicinal, Botanical, Chemical and Pharmacological Activities
}

\author{
Efrem-Fred A. Njau ${ }^{1} \&$ Patrick A. Ndakidemi ${ }^{2}$ \\ ${ }^{1}$ The National Herbarium of Tanzania, Tropical Pesticides Research Institute P.O.Box 3024, Arusha, Tanzania \\ ${ }^{2}$ School of Life Science and Bioengineering, The Nelson Mandela African Institution of Science and Technology, \\ P.O.Box 447, Arusha, Tanzania \\ Correspondence: Efrem-Fred A. Njau, The National Herbarium of Tanzania, Tropical Pesticides Research \\ Institute P.O.Box 3024, Arusha, Tanzania. E-mail: efrednjau@gmail.com
}

Received: December 8, 2016

Accepted: December 30, 2016

Online Published: September 29, 2017

doi:10.5539/ijb.v9n4p35

URL: https://doi.org/10.5539/ijb.v9n4p35

\begin{abstract}
Genus Tetradenia is belonging to plant family Lamiaceae. The genus is fairly large and comprises of twenty species. Different extracts of these Tetradenia species have been widely used in traditional medicine all through sub-Sahara Africa, part of Brazil and Asia. Many workers have reported that Tetradenia extracts possess various biological activities against antiviral, antifungal and antibacterial. For decades, some members of the Genus Tetradenia have been the subject of research to isolate and identify the active compounds present in extracts from its leaves. Several studies have been conducted to evaluate the biological activities of $T$. riparia as larvicide, insecticide, antimalarial and repellent effects on Anopheles gambiae. Leaf extracts ( $80 \%$ ethanol), tested for antimicrobial and antiviral activity, and was found to hamper the growth of Staphylococcus aureus, Candida albicans, Mycobacterium smegmatis, and Bacillus subtilis. This review intends to give the major highlights of the genus Tetradenia which will stimulate researchers into carrying out further investigations on the various species of the plant that may contribute into pharmacology industry.
\end{abstract}

Keywords: antifungual, antibacterial, antioxidant, ethnomedicine, Tetradenia

\section{Introduction}

Tetradenia is a genus of plants in the Lamiaceae (Labiatae) family; it was first described in 1830. It is native to Africa, including Madagascar (Johnson \& Phillipson, 1999). At the beginning, T. riparia was regarded as restricted to Madagascar only, until after about 150 years, the seven species of the genus was discovered in other places in Africa (Codd, 1983). All the seven species share many distinctive features with the Malagasy plants and it was concluded that the African and Malagasy plants are congeneric. However, Codd (1983) accepted only three of the species of $T$. riparia recognised at that time, reducing the other four to synonymy. This new combinations were made for T. barberae (N.E.Br) collected from the Eastern Cape of South Africa, T. brevispicata (N.E.Br) Codd from Botswana, South-west Zimbabwe and neighboring parts of South Africa, and T. riparia (Hochst.). Codd (1983) interpreted as a widespread and highly variable species extending from South Africa to Ethiopia, and West to Angola and Namibia. A fourth African species, T. kaokoensis was identified by van Jarrrsv. \& A.E. van Wyk, which was endemic to the Otjihipa Mountains of North-western Namibia. Tetradenia was revised for Madagascar by Phillipson and Hedge (1998). In the field Tetradenia plants are often quite conspicuous in their preferred rocky habitats, and they are relatively well represented in the relevant herbarium collections. However, the inflorescences in most species are produced during the dry season when the plants may be leafless (Johnson and Phillipson, 1999). These characteristics make studies on Tetradenia rather challenging because herbarium specimens often lack leaves, and representative male and female plants have only rarely been collected together. The genus is composed of twenty species as follows T. barberae (N.E.Br.) Codd, T. brevispicata (N.E.Br.) Codd, T. clementiana Phillipson, T. cordata Phillipson, T. discolor Phillipson, T. falafa Phillipson ,T. fruticosa Benth. T. galpinii (N.E.Br.) T. goudotii Briq., T. herbacea Phillipson, T. hildeana Phillipson, T. isaloensis Phillipson, T. kaokoensis van Jaarsv. \& A.E.van Wyk, T. multiflora (Benth.) Phillipson, T. nervosa Codd, T. riparia (Hochst.) Codd, T. tanganyikae Phillipson, T. tuberosa T.J.Edwards, T. urticifolia (Baker) Phillipson. 
Table 1. Phytogeographical distribution of the species of genus Tetradenia

\begin{tabular}{lll}
\hline Species name & \multicolumn{1}{c}{ Author } & Country of occurrence \\
\hline Tetradenia bainesii & (N.E.Br.) Phillipson \& C.F.Steyn & Zimbabwe, Mozambique, Swaziland, S. Africa \\
Tetradenia barberae & (N.E.Br.) Codd & Cape Province \\
Tetradenia clementiana & Phillipson & Madagascar \\
Tetradenia cordata & Phillipson & Madagascar \\
Tetradenia discolor & Phillipson & Madagascar, Zaire, Zimbabwe, Malawi, Tanzania \\
Tetradenia falafa & Phillipson & Madagascar \\
Tetradenia fruticosa & Benth & Madagascar \\
Tetradenia galpinii & (N.E.Br.) Phillipson \& C.F.Steyn & S. Africa, Tanzania, Swaziland \\
Tetradenia goudoti & Briq & Madagascar \\
Tetradenia herbacea & Phillipson & Madagascar \\
Tetradenia hildeana & Phillipson & Madagascar \\
Tetradenia isaloensis & Phillipson & Madagascar \\
Tetradenia kaokoensis & van Jaarsv. \& A.E.van Wyk & Namibia \\
Tetradenia multiflora & (Benth.) Phillipson & Ethiopia \\
Tetradenia nervosa & Codd & Madagascar \\
Tetradenia riparia & (Hochst.) Codd & S. Africa, Angola, Malawi, Tanzania \\
Tetradenia tanganyikae & Phillipson & Malawi, Tanzania, Zambia \\
Tetradenia tuberosa & T.J.Edwards & S. Africa, KwaZulu-Natal \\
Tetradenia urticifolia & (Baker) Phillipson & Central Africa, Sudan, Tanzania, Eritrea \\
\hline Source: WWW. kew . Org/Colion
\end{tabular}

Source: www. kew. org/collections/herbcol with modification.

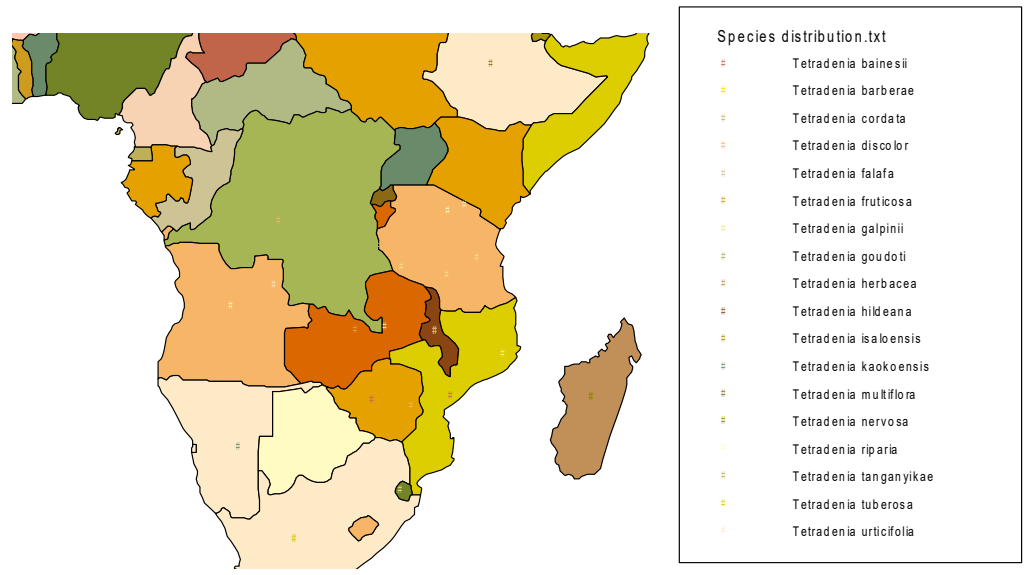

Figure1: Phytogeographical distribution of the species of genus Tetradenia in Africa

Source: Coordinates from Herbarium data.

\subsection{Botanical Description}

Members of genus Tetradenia are usually aromatic shrub up to $3 \mathrm{~m}$ in height, occasionally reaching $5 \mathrm{~m}$. (Johnson \& Phillipson, 1999). They are slightly succulent and have an irregular branch pattern. The stems are brown and smooth, except for the younger portions which are covered with glandular hairs and have a ruby tinge (Johnson \& Phillipson, 1999). The glandular hairs also cover both surfaces of the leaves and make them slightly sticky to the touch. In the species Tetradenia riparia for example, the leaves are a bright green and are slightly heart shaped with the margin irregularly and bluntly toothed. Like many Lamiaceae species the younger branches are distinctly four-angled in cross section (Beentje, 1994). Most Tetradenia species have a flavouring characteristics of a ginger plant although in a real sense have no relationship to a true ginger plant of which the underground stem is commonly used for flavouring and in preservation. The natural habitat of Tetradenia is along river banks, forest margins, dry wooded valleys and hillsides. The natural distribution ranges from South Africa to Swaziland, Namibia, Angola and northwards through Tropical East Africa, Kenya, Uganda and Tanzania to Ethiopia (Johnson \& Phillipson, 1999). 


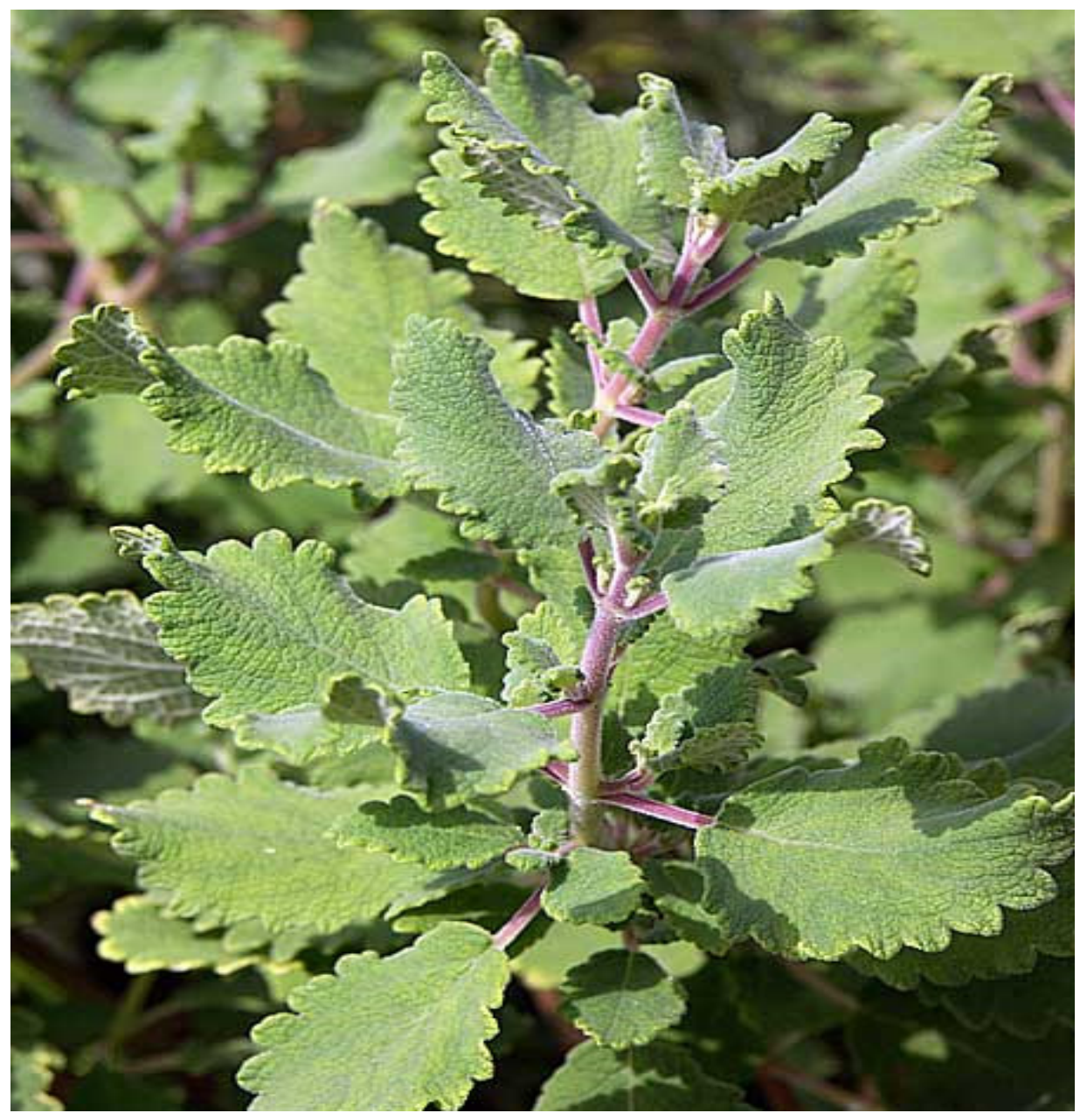

Figure 2. Tetradenia riparia as found in the field at Njari village-Kilimanjaro-Tanzania

Source: field photo (adapted from Njau et al., 2014).

\subsection{Ethnomedicinal or Traditional Use}

Tetradenia riparia has been used by traditional healers for treatment against various ailments including wound healing and skin sores (Coopoosamy \& Naidoo, 2011). The scientific validation of the use of T. riparia against some strains of Gram positive and Gram negative bacteria as well as some fungal strains has substantiated the use by traditional healers (Coopoosamy \& Naidoo, 2011). The relatively high inhibitory concentration for both bacterial and fungal strains further indicated the high value of this plant species in the medicinal world and could aid in treatment of secondary infections, such as, mouth sores, pelvic or vaginal sores in individuals who are HIV/AIDS infected. Elsewhere, tetradenia has been used throughout its range as a traditional remedy. Leaf infusion is reported to be effective against malaria (Githinji \& Kokwaro, 1993) and also leaf is chewed for dengue fever. The Tswana people in South Africa use leaf or shoot infusion for fever and also for gall sickness in cattle (Roberts, 1990). Various parts of T. riparia are used for treatment of boils and mumps in Kenya (Githinji \& Kokwaro, 1993). Leaves of T. riparia blended with banana and castor oil are useful as cattle medicine to treat insects (Hakizamungu, Van Puyvelde, Wëry, 1992). Water macerates of leaves with those of Vernonia amydalina Del. and Markhamia utea Schum are used for treatment of malaria in Rwanda (Hakizamungu, van Puyvelde, Wëry, 1992). Tetradenia plant is also used for treatment of stomach aches, mouth ulcers, toothaches, influenza and swollen legs. The plant is also used as hallucinogenic herb (Van Puyvelde, Lefebvre, Mugabo, de Kimpe, Schamp, 1985). The plant has been used for medicinal purpose by the Chagga, Pare, Meru and Maasai ethnic groups from North East regions of Tanzania. It is known as ("Ikiingiyi" or "Momboo"-in Chagga), (Ol-ikiingyi-in Maasai and Ikingilii-in Meru). The ethnopharmacological information obtained from these ethnic groups through personal interview indicates that the plant has been used against bloody diarrhea, indigestion, constipation and malaria (Njau, 2001). The fresh leaves are used to deter houseflies and mosquitoes. Moreover, Chagga, Meru and Maasai 
have used the leaves as tonic and are boiled with beef in meat camping feasts commonly known as (olupul) (Njau, 2001). In need, Tetradenia species have many uses against human and veterinary aliments in traditional healing systems.

\subsection{Pharmacological Properties}

Moderate antimalarial activity of the leaf essential oil against two strains of Plasmodium falciparum has been reported (Campbell et al., 1997). The diterpene diol 8 (14), 15-sandaracopimaradiene-7 $\alpha, 18$-diol has been shown to possess papaverine-like antispasmodic activity on methacholine, histamine and barium chloride-induced contractions of guinea pig ileum as well as on noradrenaline-induced contractions of rabbit aorta (Van Puyvelde et al., 1987). The earlier on phytochemical studies of Tetradenia riparia for instance divulged the isolation of ibozol (1) (Zelnik et al., 1978), 7 $\alpha$-hydroxyroyleanone (2) and 8 (14), 15-sandaracopimaradiene-7 $\alpha$-,18-diol (3) (van Puyvelde et al., 1978), $\alpha$-pyrones umuravumbolide (4) (Daviies-Coleman and Rivett, 1995), and tetradenolide (5) (van Puyvelde and de kimpe, 1998). The diterpenediol (3) was found to display good antimicrobial, antiplasmodic and antiparasitic activity.<smiles>CC(C)[C@H]1C(=O)C2=C3C(=O)[C@H](O)C[C@]2(C)[C@@](C)(CCCC1(C)C)[C@@H]3O</smiles>

Ibozol (1)<smiles>CCCCC(/C=C/C1CC=CC(=O)O1)OC(C)=O</smiles>

$\alpha$-pyrones umuravumbolide (4)<smiles>CCCCC(O)C(O)C(O)C1CC=CC(=O)O1</smiles>

Deacetyboronolide (7)<smiles>CC(C)[C@]1(O)CCC2=C(CC[C@@]3(C)CCCC[C@@]23C)[C@@H]1O</smiles><smiles>C=C[C@]1(C)CC[C@@]2(C)C3C[C@](C)(CO)[C@@](C)(CCCC3(C)C)[C@@]2(C)C1</smiles>

7 $\alpha$-hydoxyroyleanone (2)

8(14),15-sandaracopimarane-7 $\alpha, 18-\operatorname{diol}$ (3)<smiles>CCCCC(O)C(O)C1CC=CC(=O)O1</smiles><smiles>CCCCC(O)/C=C/C1CC=CC(=O)O1</smiles>

tetradenolide (5) deacetyllumuravumbolide (6)<smiles>CCCCC(OC(C)=O)C(O)C(O)C1CC=CC(=O)O1</smiles>

1',2'-dideacetyl-boronolide (8)

Leaf extracts ( $80 \%$ ethanol), tested for antimicrobial and antiviral activity, inhibited the growth of Staphylococcus aureus, Candida albicans, Mycobacterium smegmatis, Microsporum canis, Trichophyton mentagrophytes and Bacillus subtilis. No antiviral activity against Coxsackie virus, poliovirus (unspecified), measles virus and Semliki-Forest virus was demonstrated in these studies (Vlietinck, 1995; Boily \& van Puyvelde, 1986). Some of the observed antimicrobial activity has been attributed to the presence of diterpenes (Van Puyvelde et al., 1987). In an in vitro screen for antibacterial activity of hexane, ethanol and water extracts of South African plants, no inhibitory activity against Staphylococcus aureus, Bacillus subtilis, Escherichia coli or Klebsiella pneumoniae was demonstrated (McGaw, Jager, \& van Staden, 2000). An in vitro study of the effects of methanolic extracts of fruit, leaf, stem and root on skeletal (toad rectus abdominis), smooth (guinea pig ileum) and uterine (non-pregnant guinea pig) muscle 13 showed weak activity on uterine muscle and on smooth muscle relaxation, but strong to moderate activity on smooth muscle stimulation and on skeletal muscle. In the same study, hyper- and hypotensive effects of the extracts were tested in vivo in the rabbit, but no activity was observed in the dose used $(5 \mathrm{mg} / \mathrm{kg}$ IV) (McGaw, Jager, \& van Staden, 2000). The general toxicity of the extracts was assessed in vivo in the mouse (dose $1.0 \mathrm{~g} / \mathrm{kg} \mathrm{IP}$ ); toxic effects were recorded for root and fruit extracts but not for leaf or stem extracts (Chagnon, 1984). Insecticidal activity of methanolic extracts $(50 \mathrm{mg} / \mathrm{ml})$ of fresh and dried leaf, root and stem was assessed in vitro, using inhibition of oviposition in Rhipicephalus appendiculatus as a measure of acaricidal activity. None of the 
extracts was found to inhibit oviposition (Van Puyvelde, 1985). In a study carried out by R. M. Coopoosamy and K. K. Naidoo ( 2011) using crude extracts from leaf of Tetradenia riparia showed that all Gram positive bacteria $(\mathrm{Gram}+)$ were inhibited by the boiled water, ethyl acetate and methanol extracts obtained from leaf and stem parts of T. riparia. That was a good indication that the crude extracts have had an extremely high potential as a cure for wounds and sores and could aid in the curative properties of injuries as well as after surgical procedures (Coopoosamy \& Naidoo, 2011). This aspect is illustrated in the tables below.

Table 2. Minimal inhibitory Concentration (MIC) of Tetradenia riparia antibacterial assay on crude extracts

\begin{tabular}{llllllllll}
\hline Bacteria & \multicolumn{4}{l}{ Medium (MIC) $(\mathbf{m g} / \mathbf{m l})$} & \multicolumn{4}{c}{} & \multicolumn{3}{c}{ Control ug/ml } \\
\hline $\mathbf{1 0}^{\mathbf{6}}$ Bacteria/ ml & Gram +/- & Boiled water & Ethyl acetate & Methanol & \multicolumn{2}{c}{ Chlor $^{\mathbf{a}}$} & Strept $^{\mathbf{b}}$ \\
\hline & & Leaf & Stem & Leaf & Stem & Leaf & Stem & $<\mathbf{2 . 0}$ & $<\mathbf{2 . 0}$ \\
\hline Bacillus subtilis & + & 6.0 & 7.0 & 3.0 & 5.0 & 4.0 & 5.0 & $<2.0$ & $<2.0$ \\
Staphylococcus aureus & + & 5.0 & 7.0 & 4.0 & 5.0 & 5.0 & 5.0 & $<2.0$ & $<2.0$ \\
Staphylococcus epidermis & + & 5.0 & 6.0 & 3.0 & 5.0 & 5.0 & 6.0 & $<2.0$ & $<2.0$ \\
Escherichia coli & - & 6.0 & 7.0 & 4.0 & 7.0 & 5.0 & 6.0 & $<2.0$ & $<2.0$ \\
Proteus vulgaris & - & $\mathrm{Na}$ & $\mathrm{Na}$ & 4.0 & 6.0 & 5.0 & 6.0 & $<2.0$ & $<2.0$ \\
Enterobacter aerogene & - & $\mathrm{Na}$ & $\mathrm{na}$ & 5.0 & 7.0 & $\mathrm{Na}$ & $\mathrm{Na}$ & $<2.0$ & $<2.0$ \\
\hline
\end{tabular}

Key: $\mathrm{Na}=$ no activity, all tests were done in triplicates and the average are indicated, Chlor $^{\mathrm{a}}=$ Chloramphenicol $^{\circledR}$; Strept $\mathrm{t}^{\mathrm{b}}=$ Streptomycin sulphate ${ }^{\circledR}$

SOURCE: Coopoosamy and Naidoo, 2011.

Table 3. Effect of ethanol and aqueous extracts from Tetradenia riparia on different fungal species

\begin{tabular}{lllllllllllll}
\hline \multirow{3}{*}{ Fungal species } & \multicolumn{3}{l}{ Ethanol extract } & \multicolumn{1}{c}{ Boiled aqueous extracts } \\
\cline { 2 - 13 } & Leaf & Stem & Leaf & Stem & Leaf & Stem & Leaf & stem & leaf & stem & leaf \\
\cline { 2 - 12 } & $\mathbf{1 : 1 0}$ & $\mathbf{1 : 1 0}$ & $\mathbf{1 : 1 0 0}$ & $\mathbf{1 : 1 0 0}$ & $\mathbf{1 : 5 0 0}$ & $\mathbf{1 : 5 0 0}$ & $\mathbf{1 : 1 0}$ & $\mathbf{1 : 1 0}$ & $\mathbf{1 : 1 0 0}$ & $\mathbf{1 : 1 0 0}$ & $\mathbf{1 : 5 0 0}$ \\
\hline Aspergillus flavus & ++++ & +++ & +++ & ++ & + & + & +++ & ++ & ++ & + & - \\
Aspergillus glaucus & ++++ & +++ & +++ & ++ & + & + & ++ & + & ++ & - & - \\
Candida albicans & ++++ & +++ & +++ & ++ & + & + & ++ & + & + & + & - \\
Candida albicans & ++++ & +++ & +++ & ++ & + & + & +++ & ++ & + & - & - \\
\hline
\end{tabular}

Key: - = Negative antifungal activity, $+=$ Positive antifungal activity (low inhibition), $++=$ Positive antifungal activity (medium inhibition),$+++=$ Positive antifungal activity (high inhibition),$++++=$ Positive antifungal activity (Very high inhibition). Plates containing potato dextrose agar only served as controls. Control did not show any inhibition of any of the test fungal species.

SOURCE: Coopoosamy and Naidoo, 2011.

\subsection{Toxicology}

Bodenstein (1977) reported that there are several cases of poisoning all of which occurred in adult males in South Africa. The data were collected during 18 years of clinical practice amongst Zulu communities in South Africa across a wide geographical and socio-cultural range. The symptoms included a severe toxic inflammatory response of mucous membranes, conspicuous at all body orifices (Bodenstein, 1977). In more severe cases this went on to necrosis and large scale sloughing. A second symptom was profuse salivation; in one case an amount in excess of 5 litres of saliva was produced in 24 hours (Chagnon, 1984). In all cases of terminal illness, urine and stools consisted of almost pure blood, were dark in colour and contained shreds of exfoliated mucous membrane. Patients who were fatally ill went into anuria during the last 24-48 hours, but one man recovered after 24 hours of anuria. Most of the patients presenting with these symptoms had taken Tetradenia riparia as a cold or flu remedy, in every case exceeding the traditional dose and deviating from the accepted method of administration (Bodenstein, 1977).

\subsection{Antioxidant and Reducing Capacity of Tetradenia}

The reducing power of a compound is related to its electron transfer ability and may serve as a significant indicator of its potential antioxidant activity (Njau et al., 2014). Antioxidants, due to their free radicals scavenging activity, are useful for the management of diseases. The 2, 2-diphenyl-1-picrylhhydrazyl (DPPH) stable free radical method is a sensitive way to determine the antioxidant activity of plant extracts (Koleva et al., 2002; Suresh et al., 2008). 
The standard antioxidant- Butylated hydroxytoluene (BHT) showed the highest activity against all essential oils extracts of T. riparia. The oil extract which showed the strongest DPPH radical scavenging activity were those extracted from the dry stem parts of some species of Tetradenia. The therapeutic potential of natural medicinal plants as an antioxidant in reducing such free radical induced tissue injury, suggests that many plants have antioxidant activities that can be therapeutically useful (Kanatt et al., 2007).

\section{Conclusion}

This review has demonstrated that the genus Tetradenia possess broad spectrum antimicrobial activity and support the traditional use of the plant in ethnomedicine. Based on the traditional medicinal use of plant species of this genera among the people of sub-Sahara Africa, there is possibility of developing novel antimicrobials from one of its species. Therefore, there is a need to look for proper conservation program of this important plant species. A general trend is such that once a plant species own value interms of medicinal utilization, there is a tendency to overutilize the plant, and hence may lead into species extininction. This calls for serious conservation measure and proper management of the species.

\section{Acknowledgement}

The author wish to thank The Nelson Mandela African Institution of Science and Technology (NM-AIST) and Commission for Science and Technology (COSTECH) of Tanzania for supporting this study. The Canadian Commonwealth Scholarship program through the Canadian Bureau for International Education (CBIE) is acknowledged for their financial support that enabled me to travel and carryout part of my research work at University of Saskatchewan,-Canada.

\section{References}

Beentje, H. J. (1994). Kenya Trees, Shrubs and Lianas. National Museums of Kenya Nairobi

Bodenstein, J. W. (1977). Toxicity of traditional herbal remedies. South African Medical Journal, 52, 790-792.

Boily, Y., \& van Puyvelde, L. (1986). Screening of medicinal plants of Rwanda for antimicrobial activity. Journal of Ethnopharmacology, 16, 1-13. http://dx.doi.org/10.1016/0378-8741(86)90062-0

Campbell, W. E., Gammon, D. W., Smith. P., Abrahams, M., \& Purves, T. (1997). Composition and antimalarial activity in vitro of the essential oil of Tetradenia riparia. Planta Medica, 63, 270-272. http://dx.doi.org/10.1055/s-2006-957672

Chagnon, M. (1984). General pharmacological inventory of medicinal plants of Rwanda. Journal of Ethnopharmacol, 12(3), 239-251. http://dx.doi.org/10.1016/0378-8741(84)90053-9

Codd, L. E. (1985). The genus Tetradenia. Flora of Southern Africa, 28(4), 113-11.

Coopoosamy, R. M., \& Naidoo, K. K. (2011). Assessing the potential of Tetradenia riparia in treatment of common skin conditions in rural communities of South Africa. African Journal of Microbiology Research, 5(19), 2942-2945. http://dx.doi.org/10.5897/AJMR11.396

Githinji, C., \& Kokwaro, J. O. (1993). Ethnomedicinal study of major species in the family Labiatae from Kenya. Journal of Ethnopharmacol, 39, 197-203. http://dx.doi.org/10.1016/0378-8741(93)90036-5

Hakizamungu, E., van Puyvelde, L., \& Wëry, M. (1992). Screening of Rwandense medicinal plants for anti-trichomonas activity. Journal of Ethnopharmacol, 36, 143-146. http://dx.doi.org/10.1016/0378 $-8741(92) 90014-\mathrm{I}$

Johnson, C. F., \& Phillipson, P. B. (1999). Reproductive biology of Tetradenia Benth. (Lamiaceae). In J. Timberlake \& S. Kativus (Ed.), African Plants: Biodiversity, taxonomy and uses. Royal Botanic Gardens. pp. 97-104. http://dx.doi.org/10.1095/biolreprod61.4.892

Kanatt, S. R., Chander, R., \& Sharma, A. (2007). Antioxidant potential of mint (Mentha spicata L.) in radiationprocessed lamb meat. Food Chemistry, 100, 451-458. http://dx.doi.org/10.1016/j.foodchem.2005.09.066

Koleva, I. I., Van Beek, T. A., Linseen, J. P. H., de Groot, A., \& Evstatieva, L. N. (2002). Screening of plant extracts for antioxidant activity: acomparative study on three testing methods. Phytochemistry Analysis, 13, 8-17. http://dx.doi.org/10.1002/pca.611 PMid:11899609

McGaw, L. J., Jager, A. K., \& van Staden, J. V. (2000). Antibacterial, anthelmintic and anti-amoebic activity of South African medicinal plants. Journal of Ethnopharmacology, 72(12), 247-263. http://dx.doi.org/10.1016/ S0378-8741(00)00269-5 
Njau, E. A. (2001). An ethnobotanical study of medicinal plants used by the Maasai People of Manyara, Arusha-Tanzania. M.Sc Thesis, School of Graduate Studies, Addis Ababa University-Ethiopia. pp 95

Njau, E. F. A., Alcon, J. M., Buza, J., \& Ndakidemi, P. A. (2014). Antimicrobial Activity of Tetradenia riparia (Hochst.) Lamiaceae, a Medicinal Plant from Tanzania. European Journal of Medicinal Plants, 4(12), 1462-1478. Retrieved from www.sciencedomain.org

Phillipson, P. B., \& Hedge, I. (1998). Tetradenia Bentham. In L. Helde, R. A. Clement, A. J. Paton, \& P. B. Phillipson (ed.), Lamiacees. Flore de Madagascar et des Comores 175 (pp. 70-94). Museum National d'Histoire naturelle, Paris.

Suresh, P. K., Sucheta, S., Sudarshana, V. D., Selvamani, P., \& Latha, S. (2008). Antioxidant activity in some selected Indian medicinal plants. African Journal of Biotechnology, 7, 1826-1828. http://dx.doi.org/10.5897/ AJB2008.000-5030

Van Puyvelde, L., Lefebvre, R., Mugabo, P., de Kimpe, N., \& Schamp, N. (1987). Active principle of Tetradenia riparia ii antispasmodic activity of 8 (14), 15- sandaracopimaradiene-7a, 18-diol. Plant Medicine, 52, 156-158.

Vlietinck, A. J., Mugabo, P., de Kimpe, N., \& Schamp, N. (1995). Screening of a hundred Rwandese plants for antimicrobial and antiviral properties. Journal of Ethnopharmacology, 46, 31-47. http://dx.doi.org/10.1016/ 0378-8741(95)01226-4

Zelnik, R., Rabenhorst, E., Matida, A., Gottlieb, H. E., Lavie, D., \& Panizza, S. (1978). Ibozol, a new diterpernoid from Iboza riparia. Phytochemistry, 17, 1795-179

\section{Copyrights}

Copyright for this article is retained by the author(s), with first publication rights granted to the journal.

This is an open-access article distributed under the terms and conditions of the Creative Commons Attribution license (http://creativecommons.org/licenses/by/4.0/). 